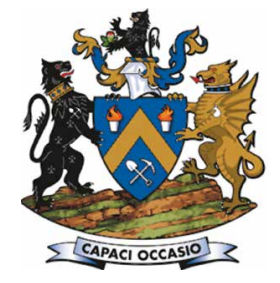

Affiliation:

${ }^{1}$ School of Geology and Geomatics, Tianjin Chengjian University, China.

2School of Resources and Geosciences, State Key Laboratory for Geomechanics and Deep Underground Engineering, China University of Mining and Technology, China.

Correspondence to:

W. Sui

Email:

suiwanghua@cumt.edu.cn

Dates:

Received: 19 Jul. 2017

Revised: 6 Apr. 2019

Accepted: 24 Apr. 2019

Published: October 2019

How to cite:

Zhang, D. and Sui, W. Orthogonal array analysis of overburden failure due to mining of multiple coal seams.

The Southern African Insitute of Mining and Metallurgy

DOI ID:

http://dx.doi.org/10.17159/24119717/17/036/2019

ORCiD ID:

W. Sui

https://orchid.0000-0001-

7004-1877

\title{
Orthogonal array analysis of overburden failure due to mining of multiple coal
}

\section{seams}

\author{
D. Zhang1 and W. Sui²
}

\section{Synopsis}

This paper presents a numerical analysis that uses an orthogonal array to investigate overburden failure caused by longwall mining of multiple coal seams. An $L N\left(s^{k}\right)$ array is said to be an orthogonal array with $s$ levels, $N$ rows, and $k$ columns. This analysis identifies the contrasting factors that influence the height of the caving and water-conducting fractured zones. The factors include the mechanical properties of the interburden layers (factor $A$ ), thickness of the interburden layers (factor $B$ ), and mining height of the lower seam (factor $C$ ). The mechanical properties of the overburden failure are quantitatively investigated and the correlations among the factors are evaluated. The results show that factors $A$, $B$, and $C$ all have a significant influence on the interactions during mining of multiple seams. This means that mining of the lower seam significantly changes the height of the caving zone of the entire system, with factors $B$ and $C$ having the most influence. Factor $B$ has a more obvious effect on the waterconducting fractured zone than factor $A$, but factor $C$ has the greatest effect among the factors. An equation to describe a dividing line, which is set to denote the relationship between the non-interaction ratio $(K)$ and the cutting height of the lower seam $(M)$ is proposed. This modified dividing line can be used to determine whether interactions exist among the overburden failure zones.

\section{Keywords}

numerical simulation, orthogonal array, multiple coal seams, water-conducting fractured zone, caving zone.

\section{Introduction}

Coal mines now face complicated geological problems and impacts from past mining activity, such as undermining or overmining) of multiple coal seams (Michaud, 1991; Mark, Chase and Pappas, 2007; Akinkugbe, 2004). The problem of mining multiple coal seams was first recognized in the $1920 \mathrm{~s}$ according to a study of ground movement and subsidence, with the first study specifically conducted by Stemple (1956).

The mining of multiple coal seams can proceed by means of four different extraction sequences (Akinkugbe, 2004; Zipf and Pittsburgh, 2005):

> Descending order, where the upper seam is first completely mined out before the lower seam is mined

- Ascending order, where the lower seam is first completely mined out before the upper seam is mined

- Simultaneous, where both the upper and lower seams are mined together or in coordination

$>$ Random order.

When extracting in ascending order, the upper seam should be located above the bendingsubsidence zone of the lower seam, that is, mining the lower seam would not compromise the structural integrity and load-bearing capacity of the upper seam, otherwise the full extraction of the lower seam would typically lead to the subsidence of the overburden beds (Mark, 2007). By contrast, when extraction is conducted in descending order, stress concentration on the pillars should be avoided (Liu, 2011). Generally, descending order is the preferred extraction sequence because there is better control of the multiple-seam mining interactions (Akinkugbe, 2004; Mark, 2007). Therefore, in the current paper we will focus mainly on the descending order of extraction.

The overburden depth, interburden thickness, and their mechanical properties, as well as the relative locations of the pillars between two seams, are the factors contributing to the stress in and instability of the lower seam (Chekan and Matetic, 1988; Chanda, 1989; Muhammad, 1993). When 


\section{Orthogonal array analysis of overburden failure due to mining of multiple coal seams}

an adequate distance exists between seams that are close together, mining the upper seam has little effect on the lower seam. However, with inadequate distance, the effect on the lower seam becomes pronounced. The roof of the lower seam may fracture, thus changing the stress environment. During the mining of multiple coal seams, the stress transferred from the upper coal seam usually results in the failure of the entry roof in the underlying seams. The mining of two seams will cause the instability of the roof, ribs, and floor of the mine and affect worker safety (Maleki et al., 1986). However, beyond this process, the percentage of hard rock in the interburden, particularly if sandstone is present, is a major factor affecting the stability of the roof during mining of the lower seam. The effect of the percentage of hard rock is even more pronounced at the mid-span of the overburden layers than at the entry roof. The distribution of hard rock influences the type and location of overburden failure. Interburden thickness is also an important factor for evaluating the instability of the lower seam. Studies have shown that the stability of the lower seam can be maintained for an interburden thickness of $6 \mathrm{~m}$ when the structural integrity of the pillars is secured (Muhammad, 1993). However, a thick interburden layer reduces the prevalence of subsidence induced by the lower coal seam, which can affect the upper coal seam. Pre-planned multi-seam mining, which is a new mining method, has been developed to avoid geological hazards such as coal outbursts in shallow, gas-rich seams; therefore, whichever seam entails the fewest hazards should be excavated first (Dou et al., 2006). The first mined coal seam is defined as the protective coal seam because it changes the initial distribution of stress in the deep surrounding rock by improving its plastic deformation capability and weakening the stress concentration during mining. The second mined seam is usually called the protected seam, and can prevent accidents because the areas above and below the goaf of the protective seam are considered stress-release zones during the mining of multiple seams (Liu et al., 2011; Zhang et al., 2014).

Overburden failure is an important factor in assessing the safety of underground mining, particularly mining under bodies of water. Sui et al. (2015) discussed the influence of the thickness of the interburdens of multiple seams and their engineering-geological properties on the interactions in the overburden of the caving and water-conducting fractured zones in a Chinese coal mine. The findings showed that when all layers have the same mechanical properties, the interactions in the overburden of the caving and water-conducting fractured zones decrease with increasing interburden thickness. The interactions cannot be neglected if the ratio of the interburden thickness to the cutting height of the lower seam is less than a defined critical value based on geological and mining conditions. However, the significance of this ratio and the main effects of the interactions on the development of overburden failure have not been sufficiently discussed in previous investigations.

Multiple seams account for a large percentage of all mining operations, and most coal mines in China experience issues arising from the interactions between the seams being mined (Zhang, 2008; Wang et al., 2015). Although theories have been proposed and practical research has been conducted on the control and regulation of wall rock in single-seam mining, most research on multiple-seam mining has been practical and empirically qualitative (Yang, Sui, and Xia, 2008; Lian, Wang, and Hao, 2010).
An $L_{N}\left(S^{k}\right)$ array is said to be an orthogonal array with $S$ levels in the most frequently used notation. $N$ is the number of rows and is also known as the size of the array. The number of columns $k$ is also called the number of factors or variables (Hedayat et al., 1999). An orthogonal array can be used to select a subset of all combinations, which is known as comprehensive testing. The test coverage can be maximized while minimizing the number of test cases by using orthogonal array testing, thereby reducing the number of tests to a reasonable amount and improving work efficiency. In the present paper we propose that an orthogonal array should be used to investigate the contrasting influences of factors such as the geotechnical properties of the overburdens, interburdens, and cutting height on the interactions during the mining of multiple seams. Moreover, the interactions of the factors contributing to overburden failure are quantitatively analysed at different levels. Here, a numerical model for the extraction of coal seams is built by using the Universal Distinct Element Code Version 4.0 (UDEC4.0), based on the Cuizhuang coal mine in Shandong, China. This numerical investigation using an orthogonal array is an effective means of investigating the effects of each factor in a multi-level factorial experiment by selecting a finite number of trials and designing a series of tables for analysing the interactions during mining of multiple seams. To efficiently determine the heights of overburden failure, an experiment based on an orthogonal array with mining of multiple seams in the Cuizhuang coal mine is used to investigate the contrasting factors in the numerical analysis and determine how they affect the height of overburden failure. The contrasting factors include the mechanical properties, the thickness of the interburden layer, and the height of mining of the lower seam. The mechanical properties of overburden failure are quantitatively investigated, and the correlations among the different factors are evaluated. A dividing line is also proposed to distinguish overburden failure zones with and without interaction.

\section{Method \\ Case study}

The case studied in this paper focuses on the engineering, geological, and mining conditions of a multiple-seam mining area, namely the Cuizhuang coal mine, which is located in the Weishan County of Shandong, China (Figure 1). The coal mine has an area of $11.9 \mathrm{~km}^{2}$, with $66 \%$ of the total coal resources under Weishan Lake. Its geological structure is generally a monocline with a set of secondary, gently undulating folds with varying strike directions and dips. However, the studied area is not affected by these folds.

The stratigraphic succession of the Cuizhuang coal mine contains sequences from the Ordovician, Carboniferous, Permian, Jurassic, and Neogene geological periods. The multiple coal seams (the upper and lower Seam no. 3), are productive coal seams in the Permian Shanxi Formation. The average thickness of the upper seam is $5.9 \mathrm{~m}$, whereas that of the lower seam is $4 \mathrm{~m}$. Zero thickness occurs in the absence of deposited sediment. The bedrocks of the mine are covered by unconsolidated layers of Neogene age with a thickness of 57.16-112.43 $\mathrm{m}$ and an average thickness of $77.56 \mathrm{~m}$; the bedrocks are thin in the northeast and thicken towards the southwest. Three aquifers and two aquifuges hydraulically separate the unconsolidated layers in the Neogene. A clay layer with a thickness of $5.31-23.18 \mathrm{~m}$ is present at the bottom, and this layer plays an important role in preventing 


\section{Orthogonal array analysis of overburden failure due to mining of multiple coal seams}

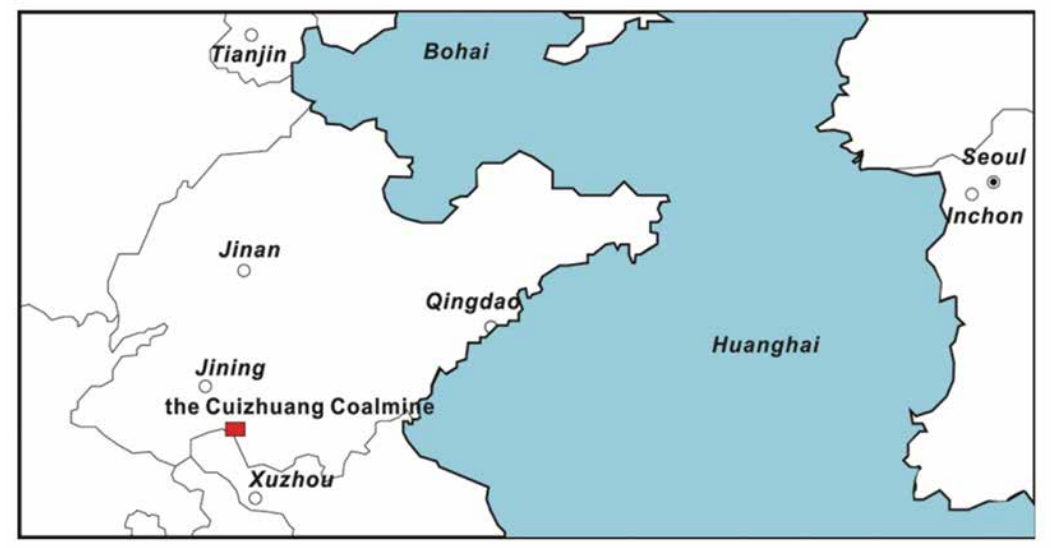

Figure 1-Location of the Cuizhuang coal mine

Table I

Geotechnical properties of typical rock types

\begin{tabular}{|c|c|c|c|c|c|c|c|c|}
\hline Rock type & $\begin{array}{l}\text { Av. thickness } \\
\text { (m) }\end{array}$ & $\begin{array}{l}\text { Density } \\
\left(\mathrm{kg} / \mathrm{m}^{3}\right)\end{array}$ & $\begin{array}{c}\text { Compressive strength } \\
\text { (MPa) }\end{array}$ & $\begin{array}{c}\text { Tensile strength } \\
\text { (MPa) }\end{array}$ & $\begin{array}{c}\text { Young's modulus } \\
\left(\times 10^{3} \mathrm{MPa}\right)\end{array}$ & $\begin{array}{l}\text { Poisson's } \\
\text { ratio }\end{array}$ & $\begin{array}{c}\text { Cohesion } \\
\text { (MPa) }\end{array}$ & $\begin{array}{c}\text { Angle of internal } \\
\text { friction }\left({ }^{\circ}\right)\end{array}$ \\
\hline Mudstone & 8.0 & 2377 & 12.25 & 0.78 & 0.32 & 0.27 & 1.45 & 31.5 \\
\hline Siltstone and fine sandstone & 15.0 & 2364 & 6.71 & 1.16 & 0.22 & 0.29 & 1.38 & 30.7 \\
\hline Interbedded mudstone and sandstone & 15.4 & 2436 & 18.01 & 2.14 & 0.97 & 0.26 & 2.68 & 32.5 \\
\hline Fine sandstone & 10.0 & 2598 & 46.79 & 1.76 & 4.79 & 0.25 & 7.60 & 33.6 \\
\hline Mudstone & 8.5 & 2537 & 41.43 & 1.78 & 3.16 & 0.24 & 4.42 & 34.8 \\
\hline Fine sandstone & 6.0 & 2651 & 100.55 & 3.66 & 10.05 & 0.23 & 13.87 & 37.5 \\
\hline Silty sandstone & 6.6 & 2621 & 65.54 & 2.08 & 11.87 & 0.26 & 4.21 & 34.5 \\
\hline Upper Seam no. 3 & 6.0 & 1476 & 5.12 & 0.34 & 0.99 & 0.25 & 2.00 & 30.0 \\
\hline Silt-sand stone & $7.0-14.0$ & 2578 & 29.68 & 1.92 & 1.01 & 0.28 & 6.12 & 31.4 \\
\hline Lower Seam no. 3 & 4.0 & 1499 & 13.82 & 0.18 & 2.21 & 0.24 & 2.10 & 30.5 \\
\hline Fine sandstone & 10.6 & 2714 & 77.97 & 4.25 & 11.68 & 0.22 & 14.04 & 35.4 \\
\hline
\end{tabular}

water inrush and seepage from the aquifers. Confined-sandstone aquifers and aquifers in fissured conglomerates in the Jurassic layers, with thicknesses of 30-60 m and specific capacities of $0.4 \mathrm{~L} / \mathrm{s} / \mathrm{m}$, have little influence at this mine because they are located over $140 \mathrm{~m}$ away from the coal seam. The greatest threat from the sandstone aquifers above the roof of both upper and lower Seam no. 3 is in the Permian layers, which have thicknesses of 15.05-58.23 $\mathrm{m}$ and specific capacities of 0-0.7 L/s/m; therefore, these layers are easily dewatered during mining. The normal water flow into the mine is stable at $40 \mathrm{~m}^{3} / \mathrm{h}$ and originates mainly from the sandstone aquifers. Therefore, the height of the water-conducting fractured zone should be carefully examined and controlled to avoid water inrush from the sandstone aquifers.

The uniaxial compression strength of the overburden layers varies from 20.11 MPa to $116.53 \mathrm{MPa}$. The thickness of the overburden varies from $36.4 \mathrm{~m}$ to more than $200 \mathrm{~m}$. The immediate roof of upper Seam no. 3 is mudstone, which is grey in colour. Thin layers with thicknesses of 0.64-0.70 m are present, and they easily cave and fill in the mined-out areas after longwall caving. The upper roof is siltstone and is dark grey in colour, and contains many plant fossils and abundant pyrite. The roof has a horizontal and slightly undulating bedding, is slightly fissured and is filled with calcite with a thickness of $6.6 \mathrm{~m}$. The interburden between the upper and lower seams is mainly grey sandy mudstone, which is about $7 \mathrm{~m}$ thick. The interburden has thin layers with horizontal bedding and fossils along the bed plane. Mudstone and fine sandstone comprise the floor of the lower seam; these rocks are horizontally bedded with vertical fissures and are composed mainly of quartz. Table I shows the geological engineering rock types and mechanical properties of the studied area, as used in the numerical modelling.

Simulated modelling is conducted in accordance with the engineering, geological, and mining conditions of this area. Two mining schemes are selected. The first scheme is the same scheme used in the original studied area and is used to verify the reliability of UDEC4.0 with regard to modelling the height of overburden failure due to mining. The second scheme uses an orthogonal test to determine which factors contribute the most to overburden failure during multiple-seam mining.

\section{Numerical simulation}

We used UDEC4.0 to simulate the areas of multiple-seam mining. UDEC is a type of two- and three-dimensional numerical software that simulates quasi-static or dynamic responses to media loading, including those of multiple intersecting joint structures. UDEC 2D was selected for this study because of the following reasons:

- 2D and 3D results are found to be very similar

- A 2D model can be solved faster than a 3D model

- A 2D model is sufficient to obtain all results in this case.

The simulated model size was set to $400 \mathrm{~m} \times 200 \mathrm{~m}$ (length $x$ height), in accordance with the conditions of the mining area. The size and stratum settings of the model were the same as those of the actual panel in order to enhance the accuracy. The 


\section{Orthogonal array analysis of overburden failure due to mining of multiple coal seams}

top of the model was set as a free displacement boundary. The displacements were fixed on both side boundaries and on the bottom. Based on previous experience in both mines (Zhang, Sui, and Liu, 2018), the height of the WCFZ cannot exceed $60 \mathrm{~m}$ due to the mining of these two seams. Therefore, a $100 \mathrm{~m}$ wide boundary was left at both sides of the panel to mitigate the boundary effect. The brick-shaped element was used and the parameters were the same as those of the actual strata. On the basis of a preliminary study on multiple-seam mining, the following factors were selected for evaluation: the height of mining of the lower seam, and the mechanical properties and the thickness of the interburden layers. Each of these factors has four levels. When two seams are closer together, the potential interaction has greater magnitude (Mark, Chase, and Pappas, 2007). The majority of the mining areas in northern China are in seams located in the Shanxi and Taiyuan formations, including both upper and lower Seam nos. 2 and 3, which have average thicknesses of 0-7.2 $\mathrm{m}$ and interburden thicknesses ranging from zero to $30.65 \mathrm{~m}$ (Kong et al., 1996). Hsiung and Peng (1987) concluded that if the thickness of the interburden is 2-3 times greater than the mining height of the upper seam during descending order extraction, no interactions are likely to occur. According to this statement, the height of the interburden layers that would most likely lead to interactions is between 10.6-15.9 $\mathrm{m}$ (where the height of the upper seam is $5.3 \mathrm{~m}$ ). According to the empirical formulae used in coal mines, assuming that only the lower seam is mined, the maximum value of the caving zone height is around 3 to 4 times the mining height (Hsiung and Peng, 1987).

An interburden thickness between 3 and $27 \mathrm{~m}$ (when the mining height ranges from $2.5 \mathrm{~m}$ to $6.5 \mathrm{~m}$ ) was selected because interburden failure may occur within this range; this measurement is consistent with actual scenarios (Sui et al., 2015).

Different types of rock were chosen to represent different types of mechanical properties in interburden failure. Four different types of rock (mudstone, siltstone, sandstone, and interbedded sandstone-mudstone) were used to simulate

\section{Table II}

Factors and levels of orthogonal experiments

\begin{tabular}{|l|c|c|c|}
\hline Level & Factor A & Factor B (m) & Factor C (m) \\
\hline 1 & Mudstone (A1) & $5.0(B 1)$ & $2.5(\mathrm{C} 1)$ \\
\hline 2 & Siltstone (A2) & $7.0(\mathrm{~B} 2)$ & $4.3(\mathrm{C} 2)$ \\
\hline 3 & Sandstone (A3) & $14.0(\mathrm{~B} 3)$ & $5.3(\mathrm{C} 3)$ \\
\hline 4 & $\begin{array}{c}\text { Mudstone and sandstone } \\
\text { interbedding (A4) }\end{array}$ & $22.5(\mathrm{~B} 4)$ & $6.5(\mathrm{C} 4)$ \\
\hline
\end{tabular}

different interburden layers. Each rock type is based on related or similar layers in the Cuizhuang coal mine, as obtained by laboratory testing.

The length of the upper and lower seams was fixed at $150 \mathrm{~m}$ because the height of the mining of the upper seam was fixed at $5.3 \mathrm{~m}$. The original parameters of the coal mine were also used in this analysis.

\section{Orthogonal array}

The factors, levels, and estimated indices are essential information in numerical experiments based on orthogonal arrays (Gong and Zhang, 2012). An orthogonal array $L_{16}\left(4^{5}\right)$ is used in this analysis because the factors considered in the array - i.e. the mechanical properties of the interburden layers (factor $A$ ), the thickness of the interburden layers (factor $B$ ), and the mining height in the lower seam (factor $C$ ) - do not interact with each other. These factors and their respective levels are shown in Table II. The various levels for factor A represent different rock types. The mechanical parameters of each rock type were used to convert factor A to numerical values in Table III, and the orthogonal trials are shown in Table IV.

\section{Results and analysis}

\section{Displacement}

Figures $2 \mathrm{a}$ and $2 \mathrm{~b}$ show the vertical displacement inside the rock domain. The maximum value always exists near the middle of the goaf, and a bilaterally symmetric funnel shape is present in the subsidence area. The maximum subsidence values of all layers range from $7.4 \mathrm{~m}$ to $11.5 \mathrm{~m}$, depending on the mining height and mechanical properties of the interburden layers.

\section{Table IV}

Orthogonal trials in the experiments

\begin{tabular}{|l|c|c|c|c|}
\hline Trial no. & Symbol & Factor A & Factor B & Factor C \\
\hline 1 & $A 1 B 1 C 1$ & Mudstone & 5.0 & 2.5 \\
2 & $A 1 B 2 C 2$ & Mudstone & 7.0 & 4.3 \\
3 & $A 1 B 3 C 3$ & Mudstone & 14.0 & 5.3 \\
4 & $A 1 B 4 C 4$ & Mudstone & 22.5 & 6.5 \\
5 & $A 2 B 1 C 2$ & Siltstone & 5.0 & 4.3 \\
6 & $A 2 B 2 C 1$ & Siltstone & 7.0 & 2.5 \\
7 & $A 2 B 3 C 4$ & Siltstone & 14.0 & 6.5 \\
8 & $A 2 B 4 C 3$ & Siltstone & 5.5 & 5.3 \\
9 & $A 3 B 1 C 3$ & Sandstone & 5.0 & 5.3 \\
10 & $A 3 B 2 C 4$ & Sandstone & 6.5 \\
11 & $A 3 B 3 C 1$ & Sandstone & 22.5 & 4.0 \\
12 & $A 3 B 4 C 2$ & Sandstone & 5.0 & 6.5 \\
13 & $A 4 B 1 C 4$ & Mudstone and sandstone interbedding & 7.0 & 5.3 \\
14 & $A 4 B 2 C 3$ & Mudstone and sandstone interbedding & 7.0 \\
15 & $A 4 B 3 C 2$ & Mudstone and sandstone interbedding & 14.0 & 4.3 \\
16 & $A 4 B 4 C 1$ & Mudstone and sandstone interbedding & 22.5 & 2.5 \\
\hline
\end{tabular}

Table III

\section{Levels of factor $A$}

\begin{tabular}{|c|c|c|c|c|c|c|c|}
\hline \multicolumn{2}{|l|}{ Factor A } & $\begin{array}{l}\text { Density } \\
\left(\mathrm{kg} / \mathrm{m}^{3}\right)\end{array}$ & $\begin{array}{l}\text { Bulk } \\
\text { (MPa) }\end{array}$ & $\begin{array}{l}\text { Shear } \\
\text { (MPa) }\end{array}$ & $\begin{array}{l}\text { Cohesion } \\
\text { (MPa) }\end{array}$ & $\begin{array}{l}\text { Angle of internal } \\
\text { friction }\left({ }^{\circ}\right)\end{array}$ & $\begin{array}{l}\text { Tensile strength } \\
\text { (MPa) }\end{array}$ \\
\hline \multicolumn{2}{|c|}{ Mudstone (A1) } & 2537 & 2025 & 1274 & 4.42 & 34.8 & 1.78 \\
\hline \multicolumn{2}{|c|}{ Siltsstone (A2) } & 2578 & 761 & 395 & 6.12 & 31.4 & 1.92 \\
\hline \multicolumn{2}{|c|}{ Sandstone (A3) } & 2651 & 6203 & 4085 & 13.87 & 37.5 & 3.66 \\
\hline $\begin{array}{l}\text { Interbedding } \\
\text { layers (A4) }\end{array}$ & $\begin{array}{l}\text { Mudstone } \\
\text { Sandstone }\end{array}$ & $\begin{array}{l}2537 \\
2651\end{array}$ & $\begin{array}{l}2025 \\
6203\end{array}$ & $\begin{array}{l}1274 \\
4085\end{array}$ & $\begin{array}{c}4.42 \\
13.87\end{array}$ & $\begin{array}{l}34.8 \\
37.5\end{array}$ & $\begin{array}{l}1.78 \\
3.66\end{array}$ \\
\hline
\end{tabular}




\section{Orthogonal array analysis of overburden failure due to mining of multiple coal seams}

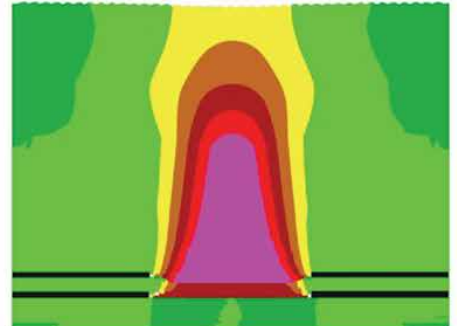

(a) Vertical displacement from Trial 7

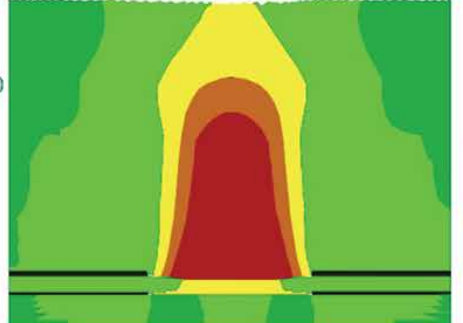

(b) Vertical displacement from Trial 11 block plot

$Y$ displacement contours

contour interval $=2.000 \mathrm{E}+00$

$-8.000 \mathrm{E}+00$ to $0.000 \mathrm{E}+00$

contour interval $=2.000 \mathrm{E}+00$

$1.000 \mathrm{E}+01$ to $0.000 \mathrm{E}+00$

$-1.000 \mathrm{E}+01$

$-8.000 \mathrm{E}+00$

$-6.000 \mathrm{E}+00$

$-4.000 \mathrm{E}+00$

$-2.000 \mathrm{E}+00$

$-0.000 \mathrm{E}+00$

Figure 2-Vertical displacement inside the rock domain

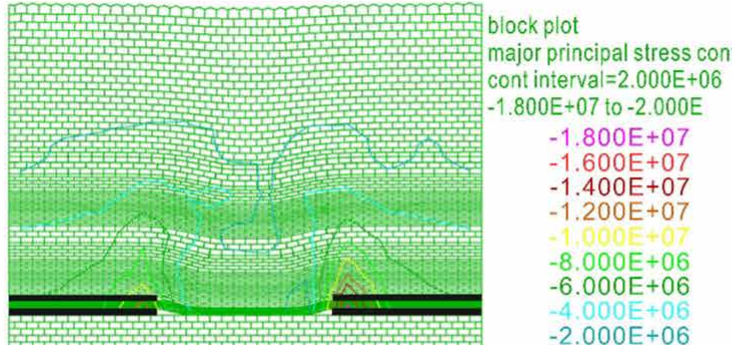

(a) Major principal stress contours

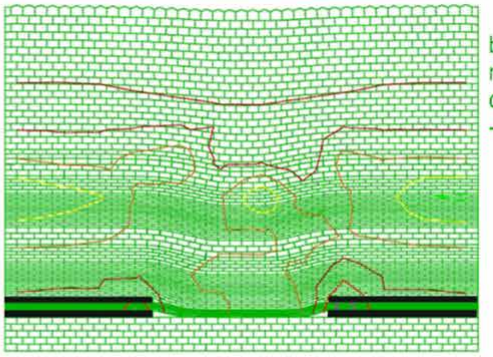

(b) Minor principal stress contours block plot

minor principal stress cont

cont interval $=1.000 \mathrm{E}+06$

$3.000 E+06$ to $2.000 E+06$

$-3.000 \mathrm{E}+06$

$-2.000 E+06$

$1.000 \mathrm{E}+06$

$0.000 \mathrm{E}+06$

$2.000 E+06$

Figure 3-Stress contours from trial 10

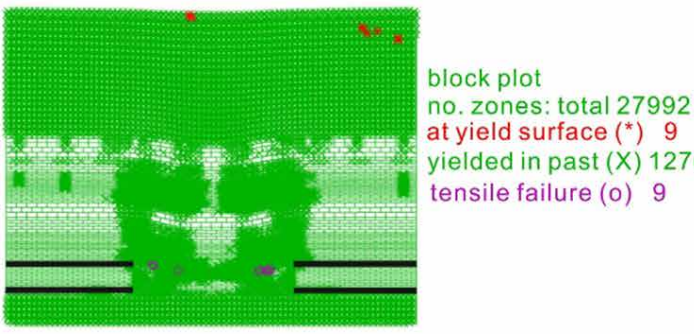

(a) Tensile failure disconnection (Trial 8)

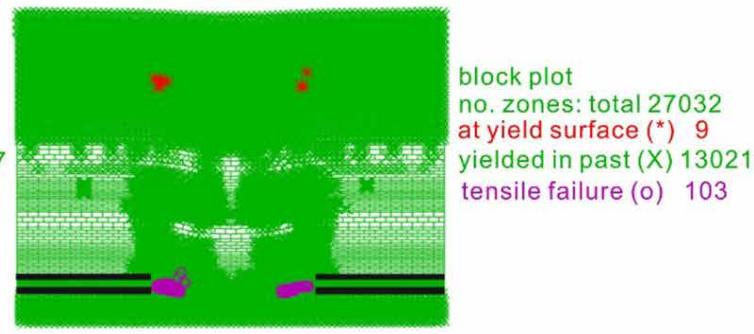

(b) Tensile failure connection (Trial 10)

Figure 4-Plastic failure zone

\section{Stress and strain}

In all trials, the major and minor principal stresses have similar distributions Figure 3) but different ranges to their values. The maximum value of the major principal stress and the minimum value of the minor principal stress occur on both sides of the pillars. In the expanded region of the pillar area and the surrounding rock, the minimum principal stress value is small. The stress redistribution area expands almost as far as the mining length outside the goaf. On the other hand, the major principal stress contours slope upward and on two sides, and the shape of the height of the contours varies with the progression of mining. As the mined distance advances, the stress values in the pillar area continue to increase, thus forming the shape of a saddle.

\section{Overburden failure}

The caving zone is assumed to be a plastic failure plus tensile failure zone, and the height of the water-conducting fractured zone is determined on the basis of shear strain, y-displacement, and development of open fractures and slip zones (Gao, Stead, and Coggan, 2014). Tensile failure and a plastic zone are found only above the upper goaf (Figure 4a), while they are found immediately above both the upper and the lower goaf and connected to form the caving zones (Figure $4 \mathrm{~b}$ ). These features can be used to determine the height of the caving zone. A sudden change occurs in the vertical displacement contour (Figure 2), and the opening fractures are disconnected from each other (Figure 5). Furthermore, the isolines become sparsely spaced and disperse to an apparent large open aperture, where they are used to determine the height of the water-conducting fractured zone in combination with shear failure (Figure 6).

When tensile failure occurs at the two ends of the panel (Figures $4 \mathrm{a}$ and $4 \mathrm{~b}$ ) and the fractures induced by mining are fully developed, the area of the water-conducting fractured zone expands. Shear failure is found above the tensile failure, and some of this failure propagates into the bottom clay layer (Figures $6 \mathrm{a}$ and $6 \mathrm{~b})$. Figure $4 \mathrm{a}$ shows an obvious interaction in the caving zone between the two panels, with tensile failure mainly found in the upper goaf. However, no interaction is found in the caving zone in Figure $4 \mathrm{~b}$, with the tensile failure separately distributed in both the goafs and the plastic zone. 


\section{Orthogonal array analysis of overburden failure due to mining of multiple coal seams}

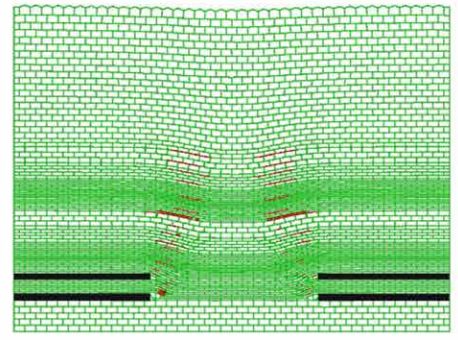

(a) Trial 7

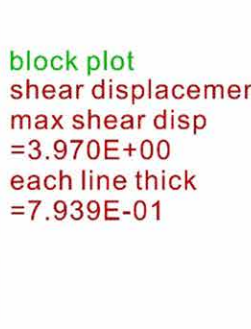

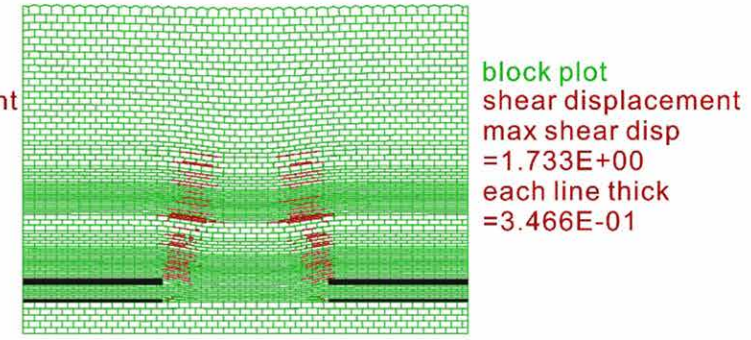

(b) Trial 11

Figure 5-Development of open fractures and slip zones

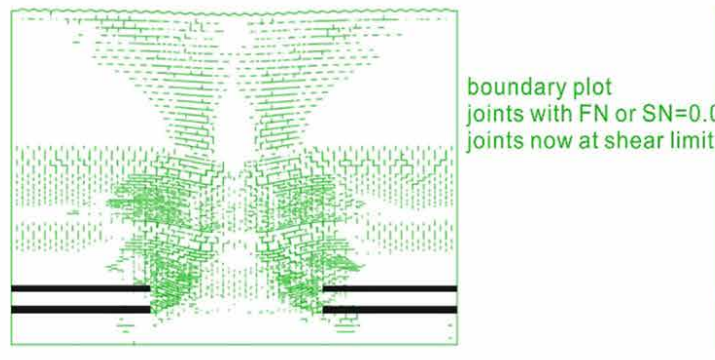

(a) Trial 7

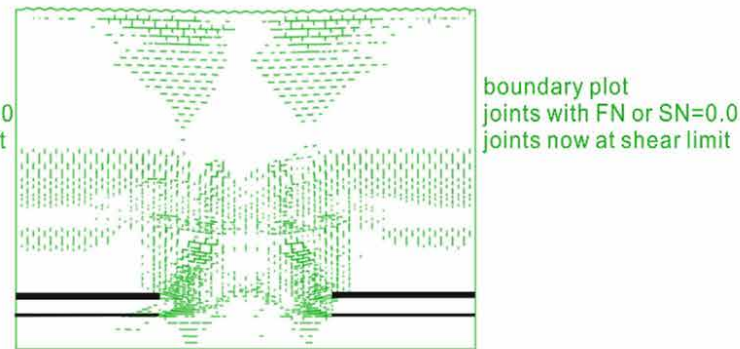

(b) Trial 11

Figure 6-Shear failure

Table $V$

Comparison of overburden failure obtained from in situ measurements, scale model test, and numerical simulation

\begin{tabular}{|c|c|c|c|c|c|c|c|c|c|}
\hline \multirow[t]{2}{*}{ Mining seam } & \multirow{2}{*}{$\begin{array}{c}\text { Mining } \\
\text { height }(\mathrm{m})\end{array}$} & \multicolumn{4}{|c|}{ Height of caving zone (m) } & \multicolumn{4}{|c|}{ Height of water flow fractured zone (m) } \\
\hline & & In situ & $\begin{array}{c}\text { Scale } \\
\text { (Sui et al. 2015) }\end{array}$ & $\begin{array}{c}\text { Numerical } \\
\text { (Sui et al. 2015) }\end{array}$ & Numerical & In situ & $\begin{array}{c}\text { Scale } \\
\text { (Sui et al. 2015) }\end{array}$ & $\begin{array}{c}\text { Numerical } \\
\text { (Sui et al. 2015) }\end{array}$ & Numerical \\
\hline $\begin{array}{l}\text { Upper } \\
\text { Lower }\end{array}$ & $\begin{array}{l}5.0 \\
4.0\end{array}$ & $\begin{array}{c}19.6 \\
-\end{array}$ & $\begin{array}{l}16.8 \\
24.5\end{array}$ & $\begin{array}{l}15.0 \\
23.0\end{array}$ & $\begin{array}{l}16.5 \\
20.9\end{array}$ & $\begin{array}{c}59.6 \\
66\end{array}$ & $\begin{array}{l}52.1 \\
68.0\end{array}$ & $\begin{array}{l}55.0 \\
64.0\end{array}$ & $\begin{array}{l}53.1 \\
61.0\end{array}$ \\
\hline
\end{tabular}

\section{Verification of the UDEC modelling of overburden failure height}

A comparison was made between in-situ measurements and the scale model tests (Sui et al., 2015) of the study area on the one hand and the results of numerical simulation under the same geological conditions on the other (Table V). The results were found to agree well; according to in situ measurements, the height of the caving zone is $19.6 \mathrm{~m}$ (the upper seam) and that of the water-conducting fractured zone is $66 \mathrm{~m}$ (both seams), whereas the respective numerically simulated results are 16.5 and $61 \mathrm{~m}$. Moreover, in a previous study, a scale model was used to determine that the heights of the caving and water-conducting fractured zones were 24.5 and $68 \mathrm{~m}$, respectively (Sui et al., 2015). Therefore, the feasibility of using numerical simulation to study overburden failure and interactions in multiple-seam mining is verified. The results show that when a narrow vertical space exists between the contour lines of Y-displacement, the value of subsidence changes quickly, and the height of the lines of the stress concentration agrees well with the height of the caving zone. The height of the water-conducting fractured zone is determined from the combination of the maximum shear displacement and the sudden change in Y-displacement, and is in good agreement with the in situ measurement.

\section{Heights of the caving and water-conducting fractured zones}

The obtained heights of the caving $\left(H_{c}\right)$ and water-conducting fractured $\left(H_{f}\right)$ zones are shown in Table VI, together with the maximum values of subsidence at different heights from the roof of the upper seam $\left(S_{n}\right)$. Each estimated index is analysed to determine its significance (Tables VII and VIII and Figure 7).

\section{Discussion}

\section{Main effects}

The use of range to analyse variance (see Table VII) is an intuitive method based on an orthogonal array format. This method can determine the impact of factors on the results of the simulation and successively rank the various incidences. Hence, we chose the range and variance-component method to analyse the numerical results. Table VII shows the ranges used to analyse variance. $k 1, k 2, k 3$, and $k 4$ represent the average values of the total extent to which the heights of the caving and water-conducting fractured zones are affected by levels $1,2,3$, and 4 , respectively. The range value, $D$, represents the difference between the maximum and minimum of $k 1, k 2, k 3$, and $k 4$. The range in the analysis of variance reflects the degree of fluctuation 


\section{Orthogonal array analysis of overburden failure due to mining of multiple coal seams}

\section{Table VI}

Results of numerical investigation using an orthogonal array

\begin{tabular}{|c|c|c|c|c|c|c|c|c|c|}
\hline Trial no. & Symbol & $h / M$ & $H_{c}(\mathrm{~m})$ & $H_{f}(\mathrm{~m})$ & $S_{50}(m)$ & $S_{80}(m)$ & $S_{120}(m)$ & $S_{160}(m)$ & $S_{\text {ground(230) }}(\mathrm{m})$ \\
\hline 1 & $A 1 B 1 C 1$ & 2.0 & 16.3 & 65.0 & 7.52 & 7.43 & 7.34 & 5.76 & 3.43 \\
\hline 2 & $A 1 B 2 C 2$ & 1.6 & 20.9 & 72.7 & 9.25 & 9.18 & 9.04 & 6.58 & 2.99 \\
\hline 3 & $A 1 B 3 C 3$ & 2.6 & 15.4(8.7L) & 68.4 & 9.32 & 9.25 & 9.11 & 6.66 & 3.10 \\
\hline 4 & $A 1 B 4 C 4$ & 3.5 & $16.8(10.5 \mathrm{~L})$ & 69.7 & 11.38 & 11.30 & 11.09 & 7.78 & 3.79 \\
\hline 5 & $A 2 B 1 C 2$ & 1.2 & 18.2 & 68.1 & 9.22 & 9.15 & 9.09 & 6.50 & 2.97 \\
\hline 6 & $A 2 B 2 C 1$ & 2.8 & 14.5 & 61.5 & 7.44 & 7.38 & 7.27 & 5.45 & 2.40 \\
\hline 7 & $A 2 B 3 C 4$ & 2.2 & 22.8 & 75.2 & 11.42 & 11.33 & 11.14 & 7.86 & 3.85 \\
\hline 8 & $A 2 B 4 C 3$ & 4.2 & 12.4 (15.6L) & 63.9 & 10.31 & 10.25 & 10.07 & 7.25 & 3.36 \\
\hline 9 & $A 3 B 1 C 3$ & 0.9 & 27.0 & 78.1 & 10.39 & 10.33 & 10.15 & 7.35 & 3.36 \\
\hline 10 & $A 3 B 2 C 4$ & 1.1 & 31.9 & 87.3 & 11.52 & 11.46 & 11.28 & 7.82 & 3.93 \\
\hline 11 & $A 3 B 3 C 1$ & 5.6 & $15.4(9.7 \mathrm{~L})$ & 56.8 & 7.70 & 7.63 & 7.53 & 5.58 & 2.44 \\
\hline 12 & $A 3 B 4 C 2$ & 5.2 & 15.6 (13.7L) & 53.9 & 9.21 & 9.14 & 9.01 & 6.58 & 3.07 \\
\hline 13 & $A 4 B 1 C 4$ & 0.8 & 26.5 & 82.4 & 11.50 & 11.44 & 11.38 & 7.90 & 3.87 \\
\hline 14 & $A 4 B 2 C 3$ & 1.3 & 24.5 & 74.4 & 10.33 & 10.21 & 9.91 & 9.78 & 9.09 \\
\hline 15 & $A 4 B 3 C 2$ & 3.3 & 12.7 (7.6L) & 63.0 & 9.30 & 9.24 & 9.10 & 6.69 & 3.02 \\
\hline 16 & $A 4 B 4 C 1$ & 9.0 & $10.5(6.4 \mathrm{~L})$ & 41.7 & 11.21 & 11.13 & 10.94 & 7.78 & 3.80 \\
\hline
\end{tabular}

Note: $\mathrm{S}_{50}$ represents subsidence of $50 \mathrm{~m}$ from the roof of the upper seam; $S$, the subsidence of the ground surface at a distance of $230 \mathrm{~m}$ from the roof of the upper seam

' $\mathrm{L}$ ' indicates that the caving zone of the lower goaf did not develop into the upper goaf and represents the height of the caving zone measured from the immediate roof of the lower seam.

\section{Table VII}

\section{Range in the analysis of variance for each estimated index}

\begin{tabular}{|l|c|c|c|c|c|c|}
\multirow{2}{*}{$\begin{array}{l}\text { For } \\
\text { levels }\end{array}$} & \multicolumn{6}{|c|}{ Average heights for factors } \\
\cline { 2 - 7 } & \multicolumn{2}{|c|}{$\mathbf{A}$} & \multicolumn{2}{c|}{$\mathbf{B}$} & \multicolumn{2}{c|}{ C } \\
\cline { 2 - 7 } & $\boldsymbol{H}_{c}(\mathbf{m})$ & $\boldsymbol{H}_{\boldsymbol{f}}(\mathbf{m})$ & $\boldsymbol{H}_{c}(\mathbf{m})$ & $\boldsymbol{H}_{\boldsymbol{f}}(\mathbf{m})$ & $\boldsymbol{H}_{c}(\mathbf{m})$ & $\boldsymbol{H}_{\boldsymbol{f}}(\mathbf{m})$ \\
\hline$k 1$ & 17.4 & 69.0 & 22.0 & 73.4 & 14.2 & 56.3 \\
$k 2$ & 16.9 & 67.2 & 23.0 & 74.0 & 16.9 & 64.4 \\
$k 3$ & 22.5 & 69.0 & 16.6 & 65.9 & 19.8 & 71.2 \\
$k 4$ & 18.6 & 65.4 & 13.8 & 57.3 & 24.5 & 78.7 \\
Range $D$ & 5.6 & 3.6 & 9.2 & 16.7 & 10.3 & 22.4 \\
\hline
\end{tabular}
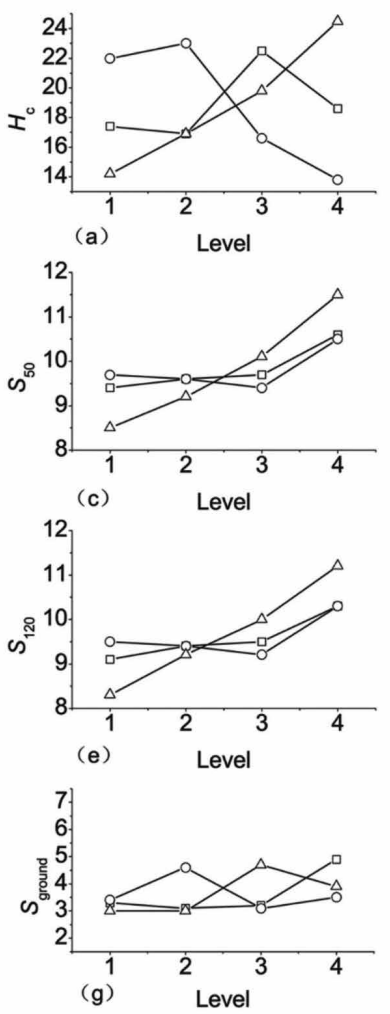

Figure 7-Relationship between levels of different factors and estimated indices in the data; a large range $(D)$ value shows that the factor has a significant effect on the interaction between the two seams and that the progressive failure of the entire overburden increases. Accordingly, the degrees to which these factors impact the heights of both the caving and water-conducting fractured zones depend on the height of the lower-seam mining, the interburden thickness, and the properties of the interburden layer (in descending order of impact).

Figure 7 shows the effects of the various factors on the estimated indices for various factor levels. When a factor has greater significance as an index, the line fluctuates greater. Figure 7 a shows that factors $B$ and $C$ have the greatest influence
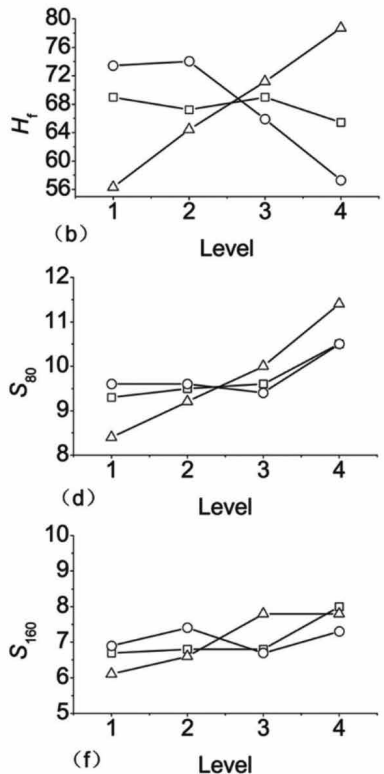

$\square A$
$\square-B$
$-\quad C$ 


\section{Orthogonal array analysis of overburden failure due to mining of multiple coal seams}

\section{Table VIII}

Analysis of variance for each estimated index

\begin{tabular}{|l|c|c|c|c|c|c|c|c|c|}
\hline Factor & $\boldsymbol{H}_{\boldsymbol{c}}$ & $\boldsymbol{H}_{\boldsymbol{c}}(\mathbf{L})$ & $\boldsymbol{H}_{\boldsymbol{f}}$ & $\boldsymbol{S}_{50}$ & $\boldsymbol{S}_{80}$ & $\boldsymbol{S}_{120}$ & $\boldsymbol{S}_{160}$ & $\boldsymbol{S}_{\text {ground }}$ & $\boldsymbol{F}_{\mathrm{a}}$ \\
\hline$A$ & $7.233^{*}$ & $<1$ & 1.746 & 1.479 & 1.466 & 1.448 & 3.243 & 1.393 & $F_{0.05(3,6)}=4.757$ \\
\hline$B$ & $21.764^{*}$ & $11.33^{*}$ & $35.662^{*}$ & 1.230 & 1.234 & 1.205 & $<1$ & $<1$ & $\mathrm{~F}_{0.1(3.6)}=3.29$ \\
\hline$C$ & $22.362^{*}$ & $<1$ & $53.263^{*}$ & $8.510^{*}$ & $8.516^{*}$ & $8.575^{*}$ & $5.712^{*}$ & 1.253 & \\
\hline
\end{tabular}

Note: Data with '*' indicates that the level of the factor is significant to the index.

on the height of the caving zone because the lines fluctuate considerably; Factor $A$ also has a significant effect. The effectiveness of these factors on $H_{c}$ are in the order of $C \approx B>$ $A$. According to Table VIII, the changes in the levels of factors $A, B$, and $C$ have a significant effect on $H_{c}$. When the height of lower seam mining (factor $C$ ) increases, the interactions caused by mining in the lower seam will increase. Increasing factor $C$ further leads to increased overburden failure, which induces secondary failure in the failure zones of the upper goaf. For factor $B$, a large interburden thickness reduces the interactions during mining of the lower seam and helps avoid the development of overburden failure in the upper seam in some cases. Therefore, as the interburden thickness increases to a certain value, little interaction will occur in the upper goaf, and the overburden failure heights of both the upper and lower goafs will not change significantly. The caving zones of the upper and lower goafs are separate and do not intersect; this phenomenon is a separate mining issue. The critical value will be discussed later. For factor A, the heights of the caving zone are smallest and largest when the interburden layers are siltstone and sandstone, respectively. This result indicates that the high values of the mechanical properties (particularly the bulk and shear modulus) of the interburden contribute to an easy transfer of overburden failure to the upper layers, thus resulting in a large height of the caving zone.

However, this relationship differs for the height of the waterconducting fractured zone (Figure $7 \mathrm{~b}$ ). Both factors $B$ and $C$ show a significant effect, whereas factor $A$ does not obviously impact the interaction. The strengths of these factors' effects on $H_{f}$ are arranged in the order of $C>B>A$. Factor $B$ significantly affects the height of the water-conducting fractured zone (Table VIII). As the interburden thickness increases, this height decreases, thus reducing the impact of the excavation of the lower seam on the upper seam. Factor $C$ significantly affects the interactions between the mining of the lower seam and the development of the waterconducting fractured zone in the upper seam.

The three factors affect $S$ with their influence being in the order $\mathrm{C}>B \approx A$. Factor $C$ significantly influences the subsidence of the overburden layers (Figures $7 \mathrm{c}-7 \mathrm{f}$ ), except for ground subsidence (Figure $7 \mathrm{~g}$ ). Survey lines are chosen at heights of 50 , 80,120 , and $160 \mathrm{~m}$ from the immediate roof of the upper goaf and the ground surface ( $230 \mathrm{~m}$ from the roof). With an increase in the mining height of the lower seam, the subsidence of each line shows an obvious increase. The trends for factor $C$ of each line are consistent for each location. The mechanical properties and thickness of the interburden (factors $A$ and $B$ ) show little influence on the subsidence because the lines of $A$ and $B$ in Figures $7 \mathrm{c}-7 \mathrm{f}$ do not fluctuate. The ground subsidence is $230 \mathrm{~m}$ from the immediate roof of the upper seam. This value

\begin{tabular}{|c|c|c|c|c|c|}
\hline \multicolumn{6}{|c|}{$\begin{array}{l}\text { Table IX } \\
\text { Results of numerical simulation }\end{array}$} \\
\hline Trial no. & Symbol & $H(\mathrm{~m})$ & $M(\mathrm{~m})$ & $K=h / M$ & $H_{c}(\mathrm{~m})$ \\
\hline 1 & $A 1 B 1 C 1$ & 5.0 & 2.5 & 2 & 16.3 \\
\hline 2 & $A 1 B 2 C 2$ & 7.0 & 4.3 & 1.6 & 20.9 \\
\hline 3 & $A 1 B 3 C 3$ & 14.0 & 5.3 & 2.6 & $15.4(8.7 \mathrm{~L})$ \\
\hline 4 & $A 1 B 4 C 4$ & 22.5 & 6.5 & 3.5 & 16.8 (10.5L) \\
\hline 5 & $A 2 B 1 C 2$ & 5.0 & 4.3 & 1.2 & 18.2 \\
\hline 6 & $A 2 B 2 C 1$ & 7.0 & 2.5 & 2.8 & 14.5 \\
\hline 7 & $A 2 B 3 C 4$ & 14.0 & 6.5 & 2.2 & 22.8 \\
\hline 8 & $A 2 B 4 C 3$ & 22.5 & 5.3 & 4.2 & 12.4 (15.6L) \\
\hline 9 & $A 3 B 1 C 3$ & 5.0 & 5.3 & 0.9 & 27.0 \\
\hline 10 & $A 3 B 2 C 4$ & 7.0 & 6.5 & 1.1 & 31.9 \\
\hline 11 & $A 3 B 3 C 1$ & 14.0 & 2.5 & 5.6 & 15.4 (9.7L) \\
\hline 12 & $A 3 B 4 C 2$ & 22.5 & 4.3 & 5.2 & 15.6 (13.7L) \\
\hline 13 & $A 4 B 1 C 4$ & 5.0 & 6.5 & 0.8 & 26.5 \\
\hline 14 & $A 4 B 2 C 3$ & 7.0 & 5.3 & 1.3 & 24.5 \\
\hline 15 & $A 4 B 3 C 2$ & 14.0 & 4.3 & 3.3 & $12.7(7.6 \mathrm{~L})$ \\
\hline 16 & $A 4 B 4 C 1$ & 22.5 & 2.5 & 9 & $10.5(6.4 \mathrm{~L})$ \\
\hline
\end{tabular}

is 20 times greater than the total mining height; therefore, these two factors have little significance for ground subsidence.

According to the above discussion and Table VII, the selection of the level of each factor that leads to the smallest overburden failure will determine the optimal combination. For instance, the optimal combination for the smallest caving zone is level 2 (sandstone) for factor $A$, level 4 (thicker interburden layers) for factor $B$, and level 1 (smallest height of lower seam mining) for factor $C$ (i.e. $A 2 B 4 C 1$ ). The optimal combination for the smallest water-conducting fractured zone is $A 4 B 4 C 1$, and that the smallest subsidence is A1B3C1.

\section{Modification of the dividing line}

According to Table VIII, whether the caving zone of the lower seam will develop into the upper goaf and intersect with the existing upper caving zone depends mostly on the thickness of the interburden layers (factor $B$ ). Given that factor $A$ has little impact and the lowest point is between 5 and $6 \mathrm{~m}$ (height of lower seam mining), 11 additional trials were conducted with the same factor $A$ but different factors $B$ and $C$. The results (Tables IX and X; Figure 8) showed that on or above the dividing line, the caving zone induced by mining the lower seam will not intersect the upper goaf. This phenomenon is defined in this paper as no interaction between the two seams. According to the numerical results, the ratio decreases when the mining height is increased from $2.5 \mathrm{~m}$ to $5.3 \mathrm{~m}$ and reaches a minimum of 2.6. The ratio of interburden thickness to the height of lower seam mining increases with increasing mining height, but only gradually. The former part of the line has also been verified in previous research (Sui et al., 2015), but the dividing line here is lower than that 


\section{Orthogonal array analysis of overburden failure due to mining of multiple coal seams}

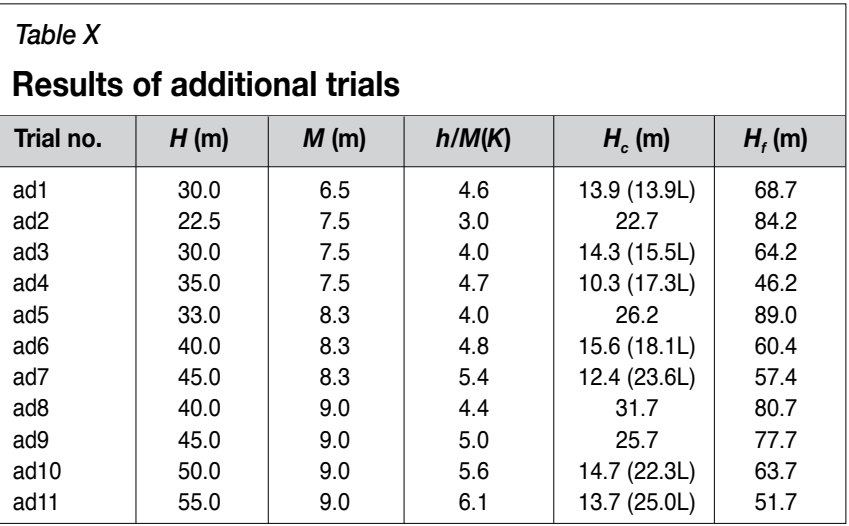

found in their work. In this study the dividing line has extended with increases in the mining height of the lower seam; the line decreases to the lowest point, and then assumes a positive slope.

Both the ratio of interburden thickness to the mining height of the lower seam $(K)$ and the mining height of the lower seam $(M)$ are assumed to conform to the 'hook function' (a type of hyperbolic function similar to an inverse function) (Figure 8). Therefore, the equation of the assumed curve is

$$
K=1.7 M+\frac{48}{M}-15.3(2<M<10) \text {. }
$$

A comparison between the test data and the assumed curve shows that when $M$ is two or greater, the two lines almost fit each other. This result shows that increases in the interburden thickness and the mining of the lower seam cause interactions to develop in the overburden failure between the two seams. First, a reduction in the interactions appears when the cutting height is between $2.5 \mathrm{~m}$ to $5.3 \mathrm{~m}$, and $K$ (the non-interaction ratio) decreases. When the cutting height continues to increase to $6 \mathrm{~m}$ or more, a larger non-interaction ratio is needed. A cutting height between 2.5 and $9 \mathrm{~m}$ is chosen because the majority of mineable seams range between $2 \mathrm{~m}$ and $10 \mathrm{~m}$ in height. The trend of a negative slope followed by a positive slope is caused mainly by the out-of-sync increasing rates of the ratio $K$ and the height of overburden failure under the same cutting height of the lower seam. The assumed equation has a minimum value of 2.77 for $K$ when $M$ is $5.31 \mathrm{~m}$. This result is consistent with the numerical result that when $M$ is $5.30 \mathrm{~m}$, the ratio value is 2.60 . The deficiency in this equation is that when $M$ is smaller than three, the value obtained by the equation is much larger than that obtained numerically.
The equation provided in this paper can help predict the possibility of the interactions of overburden failure zones due to the mining of multiple coal seams in close proximity. Therefore, overburden failure heights can be calculated by different formulae according to whether an interaction exists. The distances between the water-conducting fractured zone and the aquifers can be consequently estimated. Appropriate mining methods can be used to deal with challenges of mine groundwater and increase safety during mining.

\section{Conclusions}

This paper has discussed the factors that influence the mining of multiple seams and determined those that are significant for the development of overburden failure, as well as their optimal combination. The geological conditions, mining height of the upper seam, and mining lengths of both the upper and lower seams are constant in this paper. The numerical results are studied using range analysis and the variance-component method.

The major effects influencing overburden failure due to the mining of multiple seams were investigated. Factor $A$ is the mechanical properties of the interburden layers, factor $B$ is the thickness of the interburden layers, and factor $C$ the mining height of the lower seam.

Optimal combinations for minimizing both overburden failure and subsidence were provided. The optimal combination for the smallest height of the caving zone is $A 2 B 4 C 1$ (the lowest value of the mechanical properties, the thickest interburden layer, and the smallest mining height of the lower seam). The optimal combination for the smallest height of the water-conducting fractured zone is $A 4 B 4 C 1$ (a low value for the mechanical properties, a thick interburden layer, and the smallest mining height of the lower seam). The optimal combination for the smallest subsidence is $A 1 B 3 C 1$ (a low value of the mechanical properties, a thick interburden layer, and the smallest mining height of the lower seam).

The dividing line denoting the relationship between the noninteraction ratio $(K)$ and the cutting height of the lower seam $(M)$ was modified on the basis of whether interactions exist amongst the overburden failure zones or not. An inverse function was assumed to describe the dividing line as $K=1.7 M+{ }_{M}^{48}-15.3$ $(2<M<10)$. Therefore, this study provides the means to assess the overburden failure interactions between two closely located coal seams.

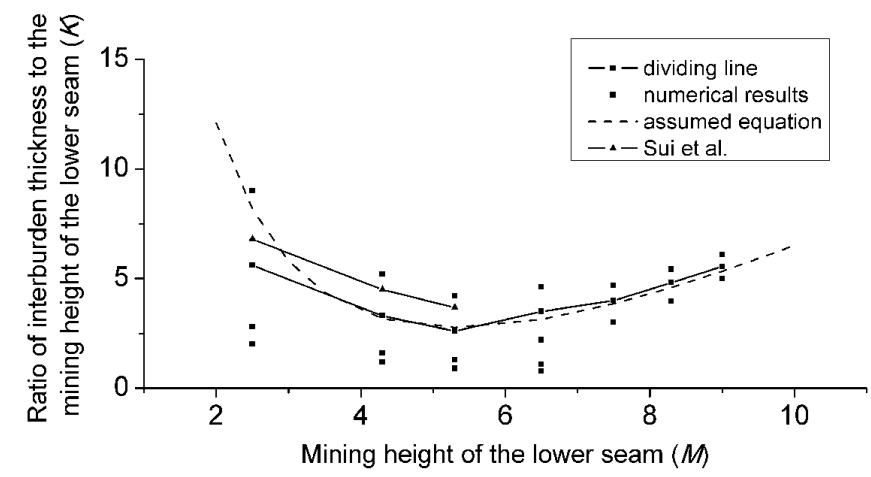

Figure 8-Dividing line of interactions in the caving zone due to the mining of multiple seams 


\section{Orthogonal array analysis of overburden failure due to mining of multiple coal seams}

\section{Acknowledgements}

The authors would like to acknowledge financial support from the National Key R\&D Program of China (Grant no. 2017YFC0804101) and the Priority Academic Program Development of Jiangsu Higher Education Institutions.. The first author was funded by the China Scholarship Council during her visit to the University of the Pacific. The authors extend their appreciation to Professor. Ravi Jain of the University of the Pacific for editorial help in preparing the manuscript. We would also like to acknowledge the reviewers for their invaluable comments.

\section{References}

AкINKugBe, 0.0. 2004. A simple two-dimensional boundary element program for estimating multiple seam interaction. Master's thesis, West Virginia University, Morgantown, WV

ChAnda, E.C.K. 1989. Evaluation of success probability in multiple seam room-andpillar mining. Mining Science and Technology, vol. 9, no. 1. pp. 57-73.

CheKan, G.J. and Matetic, R.J. 1988. Loading characteristics of pillars in multipleseam mining operations. Report of Investigations 9173. US Bureau of Mines, Pittsburgh, PA.

Dou, L.M., Zhaо, C.G., YAnG, S.G., and Wu, X.R. 2006. Prevention and Control of Rock Burst in Coal Mine. China University of Mining and Technology Press, Xuzhou, China [in Chinese].

GAo, F.Q., StEAD, D., and CogGan, J. 2014. Evaluation of coal longwall caving characteristics using an innovative UDEC trigon approach. Computers and Geotechnics, vol. 55. pp. 448-460.

Gong, X.N. and ZHANG, X.C. 2012. Excavation collapse of Hangzhou subway station in soft clay and numerical investigation based on orthogonal experiment method. Journal of Zhejiang University SCIENCE A, vol. 13, no. 10. pp. 760-767. doi:10.1631/jzus.A1200120

Hedayat, A.S., Sloane. N.J.A., and Stufken, J. 1999. Orthogonal Arrays: Theory and Applications. Springer, New York.

Hsiung, S.M. and Peng, S.S. 1987. Design guidelines for multiple seam mining, part I. Coal Mining, vol. 24, no. 10. pp. 42-46.

Kong, X.Z., Xu, H.L., Li, R.L., Chang, J.L., Liu, L.J., Zhao, X.G., Zhang, L.X., and Niu, H.C. 1996. Shanxi Late Paleozoic Era Coal-bearing Stratum and Paleontology. Shanxi Science and Technology Press, Shanxi, China [in Chinese].

LiAN, Z.S., WANG, J.R., and HAO, C.Y. 2010. Numerical simulation and experimental research of surrounding rock deformation of floor roadway under shortdistance coal seam group combined mining. Journal of Coal Science \& Engineering, vol. 16, no. 3. pp. 230-234.

Liv, C. 2011. Study on reasonable alternate distance and mining technology of 1.0 $m$ very contiguous seams simultaneous production. Master's thesis, Hebei University of Engineering, China [in Chinese].

Liu, Y.K., Zноu, F.B., Liu, C., and Hu, S.Y. 2011. An experimental and numerical investigation on the deformation of overlying coal seams above double-seam extraction for controlling coal mine methane emission. International Journal of Coal Geology, vol. 87, no. 2. pp. 139-149.
Maleki, H.N., Agapito, J.F.T., Wangsgard, M., and Cort, J. 1986. Gate road layout design for two-seam longwall mining. International Journal of Mining and Geological Engineering, vol. 4, no. 2. pp. 111-127.

MARK, C. 2007. Multiple-seam mining in the United States: Background. Proceedings of New Technology for Ground Control in Multiple Seam Mining. Mark, C. and Tuchman, R.J. (eds.). Publication No. 97-122, IC 9495. US Service, Centers for Disease Control and Prevention, National Institute for Occupational Safety and Health, Pittsburgh, PA. DHHS (NIOSH) pp. 3-14.

Mark, C., Chase, F.E., and Pappas, D.M. 2007. Multiple-seam mining in the United States: Design based on case histories. Proceedings of New Technology for Ground Control in Multiple Seam Mining. Mark, C. and Tuchman, R.J. (eds.). US Service, Center for Disease Control and Prevention, National Institute for Occupational Safety and Health, Pittsburgh, PA. pp. 15-28.

Michaud, L.H. 1991. Applications of interactive computer graphics for dragline mine planning in mountainous terrain. $\mathrm{PhD}$ thesis, Queen's University, Canada.

Muнammad, A. 1993. Stability assessment of entry roofs in underlying multiple seam mines. PhD thesis, Virginia Polytechnic Institute and State University, Blacksburg, VA.

StempLe, D.T. 1956. A study of problems encountered with multiple seam mining in the eastern United State. Master's thesis, Virginia Polytechnic Institute and State University, Blacksburg, VA.

Sul, W.H., Hang, Y., MA, L.X., Wu, Z.Y., Zhou, Y.J., Long, G.Q., and Wei, L.B. 2015. Interactions of overburden failure zones due to multiple-seam mining using longwall caving. Bulletin of Engineering Geology and the Environment, vol. 74, no. 3. pp. 1019-1035. doi: 10.1007/s10064-014-0674-9

WAng, X., BAI, J., LI, W., Chen, B., and Dao, V.D. 2015. Evaluating the coal bump potential for gateroad design in multiple-seam longwall mining: a case study. Journal of the Southern African Institute of Mining and Metallurgy, vol. 115, no. 8. pp. $755-760$.

YANG, W.F., SUI, W.H., and XIA, X.H. 2008. Model test of the overburden deformation and failure law in close distance multi-seam mining. Journal of Coal Science \& Engineering, vol. 14, no. 2. pp. 181-185.

ZHANG, B.S. 2008. Study on the surrounding rock control theory and technology of ultra-close multiple- seams mining. PhD thesis, Taiyuan University of Technology, China [in Chinese].

ZHANG, D.Y., Sul, W.H., and Liv, J.W. 2018. Overburden failure associated with mining coal seams in close proximity in ascending and descending sequences under a large water body. Mine Water and the Environment, vol. 37. pp. 322-335.

Zhang, M.W., Shimada, H., Sasaoka, T., Matsui, K., and Dou, L.M. 2014. Evolution and effect of the stress concentration and rock failure in the deep multi-seam coal mining. Environmental Earth Sciences, vol. 72, no. 3. pp. 629-643.

ZIPF, R.K. 2005. Failure mechanics of multiple seam mining interactions. Proceedings of the 24th International Conference on Ground Control in Mining. Peng, S.S., Mark, C., Finfinger, G.L., Tadolini, S.C., Heasley, K.A., and Khair, A.W. (eds.). West Virginia University, Morgantown, WV. pp. 93-106. 